\title{
The Role of Parathyroid Hormone-Related Protein (PTHRP) in the Pathophysiology of Diabetes Mellitus
}

\author{
Ioannis Legakis \\ Department of Endocrinology, Henry Dunant Hospital, Athens
}

Greece

\section{Introduction}

Blood glucose homeostasis is controlled by the endocrine cells of the pancreas, located in the islets of Langerhans. The islet cells monitor the concentration of glucose in the blood and secrete hormones with opposite effects. When after a meal the blood glucose concentration is increasing, the beta cells, which are the most numerous islet cells, secrete the hormone insulin to reduce blood glucose. Insulin stimulates the uptake of glucose by cells of the body and stimulates the conversion of glucose to glycogen in the liver. If the glucose level falls too far, islet alpha cells secrete the hormone glucagon, which stimulates the breakdown of glycogen to glucose in the liver and therefore increases blood glucose between meals. Optimal control of blood glucose levels depends on delicate changes in insulin production and secretion by the pancreatic beta cells and on their capacity for a large increase of secretion after meals, requiring large stores of insulin [1]. Very important is the need for the beta-cell mass to be closely regulated by glucose and hormonal effects on beta-cell replication, size, apoptotic elimination and, under certain conditions, neogenesis from progenitor cells. Failure to adapt to changes in body mass, pregnancy, insulin sensitivity of peripheral tissues, or tissue injury may lead to the development of chronically elevated blood glucose, or diabetes [2]. The increasing global prevalence of diabetes has stimulated efforts to develop new therapeutic strategies like beta-cell replacement or regenerative medicine. The existing therapies with exogenous insulin or hypoglycemic agents for type 1 and type 2 diabetes are unsatisfactory, since they do not offer a cure and are mostly insufficient for preventing the secondary complications associated with diabetes [3].

Despite an enormous increase in our understanding of islet differentiation and development, there is sparse information regarding the factors and pathways that regulate growth, survival, and death of islet cells. The number of islet beta cells present at birth is mainly generated by the proliferation and differentiation of pancreatic progenitor cells, a process called neogenesis. Shortly after birth, beta-cell neogenesis stops and a small proportion of cycling beta cells can still expand the cell number to compensate for increased insulin demands, albeit at a slow rate. The low capacity for self-replication in the adult is too limited to result in a significant regeneration following extensive tissue injury. Likewise, chronically increased metabolic demands can lead to beta-cell failure to compensate. Neogenesis from progenitor cells inside or outside islets represents a more potent 
mechanism leading to robust expansion of the beta-cell mass, but it may require external stimuli. For therapeutic purposes, advantage could be taken from the surprising differentiation plasticity of adult pancreatic cells and possibly also from stem cells. Recently a large number of factors controlling the differentiation of beta-cells has been identified. They are classified into the following main categories: growth factors, cytokine and inflammatory factors, and hormones such as PTHrP and GLP-1[4,5]. In general, treatment with these external stimuli can restore a functional beta-cell mass in diabetic animals, but further studies are required before it can be applied to humans.

\section{Parathyroid hormone-related peptide}

PTH-related peptide (PTHrP) was first discovered as the most frequent cause of the syndrome of humoral hypercalcemia of malignancy [6-10]. However, PTHrP mRNA is widely expressed under normal conditions, and gene ablation experiments have established that this peptide plays an essential role in normal skeletal development [11]. Human PTHrP can be produced as a 141-amino acid peptide or, through alternative mRNA splicing, as a protein comprising either 139 or 173 amino acids. PTHrP binds to the same receptor as PTH, and the biological responses elicited by either ligand through this common PTH1R-receptor are largely indistinguishable, at least with regard to mineral ion homeostasis [12-15]. For these actions of PTH and PTHrP, the amino-terminal (1-34) peptide fragments are sufficient, as PTH-(1-34) and PTHrP-(1-34) display both high-affinity receptor binding and efficient receptor activation. There is a growing body of evidence, however, suggesting that the midregional and/or carboxy-terminal fragments of either peptide, derived through posttranslational processing mechanisms, also have biological activity [16-18]. However, the observed activities of midregional and COOH-terminal fragments of PTH and PTHrP are unlikely to be related to adult mineral ion homeostasis and are probably mediated through receptors that are distinct from the PTH1R, although these receptors have not yet been identified.

\section{Structure-activity relations in PTH and PTHRP}

PTH and PTHrP show significant sequence homology within the first 13 amino acid residues (Fig1), and this sequence conservation reflects the functional importance of the amino-terminal residues in receptor signaling [19- 21]. Between PTH and PTHrP, sequence homology decreases markedly in the 14-34 region, where only three amino acids are identical, and beyond residue 34 there is no recognizable similarity.

For both PTH and PTHrP, the 15-34 region functions as the principal PTH1R binding domain, and these portions of the two peptides probably interact with overlapping regions of the receptor, as the two fragments compete equally for binding with radiolabeled PTH(1-34) or PTHrP-(1-36) to the PTH1R [22,23].These findings also suggest that the two divergent receptor binding domains of PTH and PTHrP adapt similar conformations.

The three-dimensional crystal structures of PTH or PTHrP are not known, but the peptides have been analyzed extensively by nuclear magnetic resonance (NMR) spectroscopic methods. In general, these studies indicate that, under certain solvent conditions, PTH-(134) and PTHrP-(1-36) analogs contain defined segments of secondary structure, including a relatively stable a-helix in the carboxy-terminal receptor-binding domain, a shorter less stable helix near the aminoterminal activation domain, and a flexible hinge or bend region connecting the two domains [24-26]. 


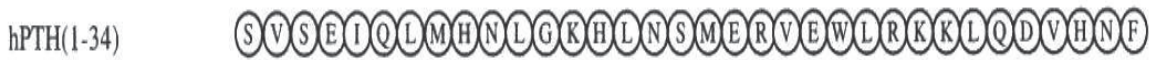

\section{$\operatorname{hPTHrP}(1-34)$ (differences only)

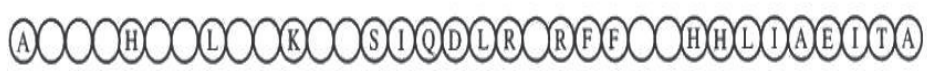

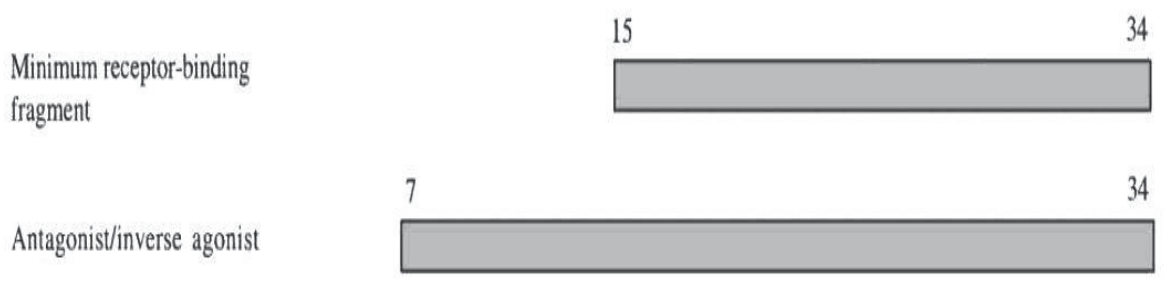

Fig. 1. Parathyroid hormone (PTH) and PTH-related peptide (PTHrP) and analogs: functional domains and receptor selectivity determinants. A: amino acid sequences of the bioactive (1-34) regions of native human PTH and human PTHrP. In the schematic of human PTHrP, only residues that differ from human PTH are provided, and amino acids that are identical to the corresponding residues of PTH are represented by open circles. Bars represent peptide fragments that exhibit weak receptor binding (15-34) or antagonist and inverse agonist properties (7-34)

Although most NMR solution studies find evidence for peptide flexibility, the question of whether the conformations of PTH and PTHrP recognized by the receptor are folded with tertiary interactions, as suggested by some studies [27-29], or extended, as suggested by other analyses, remains unanswered.

\section{Receptors for PTH and PTHRP}

As indicated above, PTH and PTHrP mediate their actions primarily through the PTH1R PTH/PTHrP receptor, a G protein-coupled receptor (GPCR) with seven membranespanning helices[30]. The PTH1R forms, along with the receptors for secretin, calcitonin, glucagon, and several other peptide hormones, a distinct family of GPCRs that exhibit none of the amino acid sequence motifs found in the other subgroups of the superfamily of heptahelical receptors [31-32]. These peptide hormone receptors, called class II or family B receptors [31], can be distinguished from other GPCRs by their large, (150 amino acid) amino-terminal extracellular domain containing six conserved cysteine residues, as well as by several other conserved amino acids that are dispersed throughout the NH2-terminal domain, the membrane-embedded helixes, and the connecting loops.

Significant progress has been made in understanding the role of the common PTH/PTHrP receptor, the PTH1R, in mammalian biology, particularly with regard to its normal role in chondrocyte growth and development, and its pathological role in two rare genetic disorders in humans. Amino acid residues in the PTH1R and PTH2R that are likely to be 
important for ligand-receptor interaction and for signal transduction have been identified through mutagenesis methods and through photoaffinity cross-linking techniques.

Although these studies have provided new insights into the mode of ligand-receptor interaction, there is still much that needs to be learned about this complex process.

\section{Pancreas development}

The pancreas originates from the foregut endoderm as ventral and dorsal buds, beginning at embryonic day (e) 9.5 in the mouse, and the two buds later fuse at approximately e12.5 [33]. The endodermal epithelium proliferates in response to various fibroblast growth factors (FGFs) produced by the adjacent mesenchyme [34], undergoes branching morphogenesis, and differentiates into ductal, exocrine, and endocrine cells. Evagination and development of the ventral pancreatic bud is slightly delayed compared with that of the dorsal bud, and the ventral bud gives rise to fewer endocrine cells than does the dorsal bud [35]. The ventral and dorsal buds also differ with regard to the signals they require for development.

\subsection{Dynamic changes in an organism's B-cell mass}

In addition to maintaining $\beta$-cell mass under normal circumstances, as just discussed, an organism must also be able to alter its $B$-cell mass in accordance with its requirements for insulin. In states of insulin resistance, such as pregnancy and obesity, B-cell mass is known to increase [45]. Such $B$-cell mass expansion is accomplished primarily by increasing $B$-cell proliferation, although neogenesis may also contribute. However, when compensatory B-cell mass expansion is inadequate, diabetes ensues - gestational diabetes in the case of pregnancy, and type II diabetes in the case of obesity. Although the majority of humans do not become diabetic in these circumstances, a significant portion of the population is predisposed to $B$-cell failure, for currently unknown reasons. It is likely that factors that regulate $B$-cell proliferation may play a role, although whether the factors that regulate B-cell mass expansion are the same as those that regulate $\beta$-cell mass maintenance is unclear.

\subsection{Regulatory factors of $b$-cell mass expansion and maintenance}

During pregnancy, rats exhibit a greater than $50 \%$ increase in $\beta$-cell mass, which is accomplished primarily through an approximate threefold increase in B-cell proliferation [46]. The chief stimuli of B-cell proliferation during pregnancy are placental lactogens (PLs), although prolactin (Prl) and growth hormone (GH) also have similar effects on B-cells and are also elevated during pregnancy. After delivery, $B$-cell mass returns to normal levels within 10 days through increased $ß$-cell apoptosis, decreased $B$-cell proliferation, and $B$-cell atrophy.

Diet-induced obesity results in insulin resistance and $ß$-cell mass expansion in humans and mice. The C57Bl/ 6 mouse strain is notoriously susceptible to these effects, exhibiting a 2.2fold increase in $\$$-cell mass and proliferation after 4 months on a high-fat diet versus a control diet [51]. However, these mice eventually become diabetic and lose their $\beta$-cell mass due to increased $B$-cell apoptosis and reduced $B$-cell proliferation.

In genetic models of obesity and insulin resistance, there is also a compensatory expansion of $\beta$-cell mass. For example, $d b / d b$ mice, which lack a functional leptin receptor, exhibit a twofold increase in $B$-cell mass by 8 weeks of age [52]. This timepoint correlates with the onset of diabetes, which progresses from glucose intolerance that is first observed between 4 
and 6 weeks of age. A similar rat model, the Zucker diabetic fatty (ZDF) rat $(f a / f a)$, also has a homozygous mutation in the gene encoding the leptin receptor. ZDF rats exhibit increased $\beta$-cell mass and increased $\beta$-cell proliferation prior to the onset of diabetes, but increased $B$ cell apoptosis prevents them from adequately expanding their B-cell mass after the onset of diabetes, despite continued high rates of $B$-cell proliferation [53]. This phenotype contrasts with what is observed in non-diabetic Zucker fatty $(\mathrm{ZF})$ rats, which possess the same mutation as ZDF rats and also become obese and insulin resistant but do not develop diabetes due to sufficient $\beta$-cell mass expansion through increased $B$-cell proliferation, neogenesis, and hypertrophy [53].

Another model of insufficient $\beta$-cell mass expansion is the insulin receptor substrate two null mouse [Irs2-/-; 54]. Global inactivation of Irs2 results in severe insulin resistance, both centrally in the brain causing obesity, and peripherally, for which B-cell mass expansion should be able to compensate. However, because $\beta$-cells require Irs2 for proper proliferation and function, Irs2-/-mice are unable to expand their B-cell mass, and they develop diabetes by 10 weeks of age. This phenotype is not observed in Irs1-/-mice, despite the fact that these mice exhibit similar insulin resistance, because Irs1 is not required for $\beta$-cell mass expansion. These experiments provide additional evidence that Irs2 is required for B-cell mass expansion in response to insulin resistance. Furthermore, overexpression of Irs2 in B-cells (Rip-Irs2) is sufficient to prevent $B$-cell failure in diet-induced obesity and streptozotocininduced diabetic models [55].

\section{The role of PTHrP in diabetes}

PTHrP was discovered in the early 1980 s as the factor responsible for humoral hypercalcemia of malignancy. Subsequent studies found PTHrP expression to be widespread in almost all tissues and organs of the body. One such tissue is the islet of Langerhans, in which all four endocrine cell types $(\alpha, \beta, \gamma$ and $\delta$ pancreatic polypeptide cells) produce PTHrP. Not only is the peptide made in islets, but receptors for PTHrP also seem to be present on $B$ cells. To begin to evaluate the possible role of PTHrP in pancreatic islets, transgenic mice overexpressing PTHrP in the $B$ cells of islets were developed using the rat insulin II promoter (RIP). These RIP-PTHrP mice displayed islet cell hyperplasia, significant hypoglycemia under both fasting and nonfasting conditions, as well as inappropriate hyperinsulinemia. Insulin expression was shown to be up-regulated both at the messenger RNA and protein level in whole pancreas of RIP-PTHrP mice. [58]

PTHrP is a prohormone that is posttranslationally endoproteolytically cleaved to yield a family of mature secretory peptides [58-60]. These include an amino-terminal secretory form, which binds to and activates the recently cloned parathyroid hormone receptor [10] , as well as several other mid-region, and carboxyl-terminal secretory forms of the peptide. Since the full-length PTHrP(1-141) cDNA was used to construct the transgene, these experiments do not provide information regarding which of the several secretory forms is (or are) responsible for the hyperinsulinemia and islet hyperplasia observed.

The phenotype does not seem to result from a developmental effect of PTHrP on the pancreas, because transgenic mice at 1 week of age were normoglycemic and displayed normal islet mass despite expression of the PTHrP transgene. In contrast, a visible increase in islet mass (2-fold) was observed in RIP-PTHrP mice by 12 weeks of age, and increased further (3- to 4-fold) by 1 yr of age. Both an increase in the number of $B$ cells per islet as well as an increase in total islet number contribute to the enhancement of islet mass in these mice. 
The increase in islet mass in RIP-PTHrP transgenic mice does not seem to be a result of an increase in the proliferation rates of preexisting $B$ cells of the islet. Thus, the increased islet mass in RIP-PTHrP mice most likely results from a decrease in the normal rate of B-cell turnover or apoptosis and/or enhanced neogenesis(62). In other cell types like chondrocytes, neuronal cells, and prostate carcinoma cells, PTHrP has been shown to have an antiapoptotic or protective effect against cell death. In line with this, $B$ cells of the RIPPTHrP mice have also been shown to be more resistant to the cytotoxic effects of high doses of the diabetogenic agent streptozotocin (STZ): RIP-PTHrP transgenic mice remain relatively euglycemic unlike their normal littermates, which become severely diabetic following STZ injection. Histologically, the resistance to the diabetogenic effects of STZ seems to result, at least partially, from PTHrP-induced resistance to STZ-mediated B-cell death (63).

Another surprising feature of the RIP-PTHrP mouse is that despite impressive overproduction of $\mathrm{PTHrP}$, systemic hypersecretion of $\mathrm{PTHrP}$ does not occur and hypercalcemia does not develop. This is surprising because PTHrP is clearly sorted into the regulated secretory pathway [64-67], and is copackaged with insulin in islet cells [66], and is secreted in response to insulin secretagogues [66]. This may reflect clearance of PTHrP by the liver after it is secreted into the portal circulation.

These findings suggest that PTHrP may have potential in therapeutic strategies designed to increase $B$-cell mass and function. Specifically, this peptide could prove to be valuable in improving islet transplant survival in type 1 diabetes.

Recently, the discovery of a family of islet homeobox genes including PDX1/STF1/IPF1/IDX1, ISL1, PAX-4, PAX-6, NeuroD/ B-2 and others [74-77] and putative islet growth factors such as GH, PRL, placental lactogen, hepatocyte growth factor, the reg family of proteins, and the recently identified protein, INGAP [78-80] has focused attention on the mechanisms responsible for pancreatic and islet development and on the mechanisms whereby islet neogenesis occurs in states of islet injury, subtotal pancreatectomy, or pregnancy, and whereby normal islet mass is sustained throughout life. If PTHrP does not have an obvious role in islet cell proliferation or in apoptosis of existing islets but is nevertheless very potent in increasing islet mass, it is possible that PTHrP may play a role in normal islet neogenesis or in differentiation from uncommitted precursor cells, such as ductular epithelial cells. In this regard, it has been reported that PTHrP is indeed expressed in pancreatic ductular cells [81].

For attaining a well-functioning $\mathrm{B}$-cell mass, $\mathrm{PTHrP}$ is a very promising candidate among insulinotropic peptides including hepatocyte growth factor, GLP-1, and exendin-4 [82]. Indeed, rat insulin gene-promoted overexpression of PTHrP in mouse islets presented a twofold increase in total islet number and total islet mass, as well as in insulin content [83]. In contrast, transgenic mice expressing exendin-4, a long-acting GLP-1-like peptide, presented no remarkable change in total islet number and total islet mass [84]. Thus, PTHrP seems to be potent in upholding a well-functioning $ß$-cell mass.

\section{Preleminary clinical observations}

As had been the case in so many other tissues, the observation of physiological and pathophysiological responses to PTH was documented in the islet and in insulin target tissues long before the discovery of PTHrP. The significance of these observations was difficult to fathom at the time, since no obvious physiological link between calcium homeostasis and glucose metabolism readily suggested itself. For example, it had long 
been observed that glucose intolerance and frank diabetes occurred in association with hyperparathyroidism more often than would be expected by random coincidence [85]. It also had been shown that the elevated PTH concentrations in patients with primary hyperparathyroidism induced both mild peripheral insulin resistance and augmented insulin response to hyperglycemia. In the majority of reports, the data on insulin response are difficult to interpret because of the effects on insulin secretion of the hypercalcemia that accompany the elevated circulating PTH concentrations in patients with hyperparathyroidism. In one study, however, normal volunteers made hypercalcemic by PTH injection over 8 days demonstrated augmented insulin responses to glucose and to intravenous tolbutamide, while a control group rendered similarly hypercalcemic by calcium infusion failed to demonstrate an augmented insulin response to glucose [86]. To investigate the direct effects of PTH on pancreatic islets in vitro, Fadda et al. [87], before the description of PTHrP as an islet peptide,examined insulin secreation from isolated pancreatic islets in response to PTH-(1-34) and PTH- (1-84). These studies showed that PTH augmented both the first and second phases of secretion in response to $16.7 \mathrm{mM}$ glucose.

The suggested link between parathyroid gland function and the pancreatic islet was met, quite appropriately, with skepticism and for two reasons. First, as noted above, it was very difficult to envision a physiological scenario in which PTH could be construed as participating in normal islet regulation. Second, studies such as that reported by Fadda et al. [87] generally required concentrations of PTH far in excess of those encountered in hyperparathyroidism to observe an effect. One was therefore forced to conclude either that these effects were nonphysiological and therefore meaningless or to postulate that there is another natural peptide of physiological import within the islet that might be mediating these effects in the islet. At the time these studies were performed, no such normal islet product was known. As is now obvious, islet derived PTHrP is a candidate worthy of consideration.

In 1992,Ishida et al,[88] reported that type 2 diabetics presented higher serum PTHrP levels than control subjects. However, in that study no stimulation tests were done to demonstrate whether PTHrP is released from the pancreas in response to insulin secretagogues like glucose or calcium. Extensive studies have demonstrated that an increase in the cytosolic calcium is essential for glucose-stimulated insulin release[89]. Indeed, one of the mature, secretory forms of PTHrP, called mid-region PTHrP, was demonstrated by $\mathrm{Wu}$ et. al. [90] to increase cytosolic calcium levels in a pancreatic b cell line. Increased cytosolic calcium levels have also been reported in insulinoma cells, supporting the notion that PTHrP is not only secreted by pancreatic cells, but might also play an autocrine or paracrine role within the islets themselves[91].In 2006,Shor et al [92] examined the effects of two stimulatory secretagogues -glucose and calcium-after an oral glucose load (75gr) to healthy controls. They reported that PTHrP and insulin rose in parallel although this response was not observed during the calcium load. Moreover, they found significant differences in basal serum PTHrP levels particularly in type 2 versus type 1 diabetics and healthy controls. Ishida et al[88], proposed that elevated PTHrP levels might play a compensatory role in calcium homeostasis in diabetic patients. They speculate that these patients often exhibit osteopenia and lower than normal PTH levels with a net result the preservation of normal serum calcium levels. 
Performing PTHrP serum determinations in a fasting state in type 2 diabetics by our group [93] we have found that PTHrP was statistically significant correlated with glucose in type 2 diabetes (r:0,992-p<0,0001) and in normal subjects in the fasting state $(r: 0,908-p<0,0001)$. Additionally, PTHrP serum levels exhibited a significant increase in type 2 diabetes compared to control subjects (Diabetics-PTHrP(Median):380 pg/ml versus NormalsPTHrP(Median):180 pg/ml , p<0,001). Interestingly, PTHrP showed a positive correlation with insulin levels only among healthy individuals presumably due to defective glucose stimulated insulin secretion known to occur in type 2 diabetics.

In conclusion, the recognition that PTHrP-a protein mostly indentified as a tumor product in cases of humoral malignant hypercalcemia, is found in almost every body tissue including the pancreas, where it is processed into multiple secreatory forms,co-packed with insulin, and secreted in a regulatory fashion in response to insulin secretagogeus, opens new directions in the autocrine/paracrine role of PTHrP in the islets of Langerhans and raises several questions for further experimentation in both type 1 and type 2 diabetes.

\section{References}

[1] Chang-Chen KJ.; Mullur R.; Bernal-Mizrachi E :Beta-cell failure as a complication of diabetes. Rev Endocr Metab Disord .,2008, 9, 329-343.

[2] Retnakaran R.;Qi Y.; Sermer M.; Connelly PW.; Hanley AJ.; Zinman B : Glucose intolerance in pregnancy anf future risk of pre-diabetes or diabetes. Diabetes Care., 2008, 31, 2026-2031.

[3] Nathan, D.M :Long-term complications of Diabetes Mellitus. N Engl J Med., 1993,328, 1676-1685.

[4] Legakis I.;Tsioras C.; Phenekos C : Decreased glucagon-like peptide 1 fasting levels in type 2 diabetes .Diabetes Care .,2003, 26, 252.

[5] Legakis I.;Mantouridis T.;Mountokalakis T : Positive correlation of galanin with glucose in type 2 diabetes . Diabetes Care., 2005, 28, 759-760.

[6] Mangin, M. A. C.; Webb. B. E.; Dreyer, J. T.; Posillico, K.; Ikeda, E. C.;Weir, A. F.; Stewart, N. H.; Bander, L. ;Milstone, D. E.; Barton, U. ;Francke, Broadus, A.E: Identification of a cDNA encoding a parathyroid hormone-like peptide from a human tumor associated with humoral hypercalcemia of malignancy. Proc. Natl. Acad. Sci. USA., $1988,85,597-601$.

[7] Moseley, J. M.; M. Kubota, H.; Diefenbach-Jagger, R. E. H.;Wettenhall, B. E. Kemp.; L. J. Suva.; C. P. Rodda.; P. R. Ebeling.; P. J. Hudson.; J. D. Zajac and J. T. Martin : Parathyroid hormone-related protein purified from a human lung cancer cell line. Proc. Natl. Acad. Sci. USA,1987, 84, 5048-5052.

[8] Stewart, A. F. R.; Horst, L. J. ;Deftos, E. C. ;Cadman, R. Lang.; Broadus,A.E: Biochemical evaluation of patients with cancer-associated hypercalcemia. Evidence for humoral and non-humoral groups. N. Engl. J. Med., 1980, 303, 1377-1381.

[9] Strewler, G. J.; Stern, P.H.; Jacobs, J.W.; Eveloff,J.; Klein, R.F.;Leung, S.C.; Rosenblatt, M.;Nissenson, R.A: Parathyroid hormone-like protein from human renal carcinoma cells. Structural and functional homology with parathyroid hormone. J. Clin. Invest., 1987, 80, 1803-1807.

[10] Suva, L. J.;Winslow, G. A.; Wettenhall, R. E. ;Hammonds, R. G. ;Moseley, J. M.; Diefenbach-Jagger, H.; Rodda, C. P.; Kemp, B. E. ; Rodriguez, H.; Chen, E. Y. ;Hudson, P. J. ; Martin, J. T.;Wood, W. I :A parathyroid hormone-related protein 
implicated in malignant hypercalcemia: cloning and expression. Science., 1987,237, 893-896.

[11] Karaplis, A. C.;Luz,A.; Glowacki, J.;Bronson,R.; Tybulewicz,V.; Kronenberg, H. M. ;R. C. Mulligan, R. C.: Lethal skeletal dysplasia from targeted disruption of the parathyroid hormone-related peptide gene. Genes Dev.,1994, 8, 277-289.

[12] Everhart-Caye, M.; Inzucchi, S.E.; Guinness-Henry, J.; Mitnick,M.A.; Stewart, A.F.: Parathyroid hormone (PTH)-related protein(1-36) is equipotent to PTH-(1-34) in humans. J. Clin. Endocrinol. Metab., 1996, 81, 199-208.

[13] Fraher, L. J.; Hodsman, A. B.;Jonas,K.; D. Saunders,D.; Rose,C.I.; Henderson, J.E.; Hendy, G.N.; Goltzman, D: A comparison of the in vivo biochemical responses to exogenous parathyroid hormone-(1-34) [PTH-(1-34)] and PTH-related peptide-(134) in man. J. Clin. Endocrinol. Metab., 1992, 75, 417-423.

[14] Horiuchi, N.;Caulfield, M.P.;Fisher, J.E.;Goldman, M.E.; McKee, R.L.; Reagan, J.E.; Levy, J.J;Nutt, R.F.; Rodan, S.B.; Schofield, T.L.; Clemens, T.L.; Rosenblatt, M : Similarity of synthetic peptide from human tumour to parathyroid hormone in vivo and in vitro. Science., 1987, 238, 1566-1568.

[15] Kemp, B. E.; Mosely, J.M.; Rodda, C.P.; Ebeling, P.R.; R. E. Wettenhall, H.; Stapleton, D.; Diefenbach-Jagger, H.; Ure, F.; Michelangali, V.P.; Simmons, H.A.; Raisz, L.G.; Martin, T.J: Parathyroid hormone-related protein of malignancy: active synthetic fragments. Science., 1987, 238, 1568-1570.

[16] Kovacs, C. S.; Lanske, B.; Hunzelman, J.L.; Guo, J.; Karaplis, A.C.; Kronenberg, H.M: Parathyroid hormonerelated peptide (PTHrP) regulates fetal placental calcium transport through a receptor distinct from the PTH/PTHrP receptor. Proc. Natl. Acad. Sci. USA., 1996, 93, 15233-15238.

[17] Potts, J. T. Jr.; Juppner, H. Parathyroid hormone and parathyroid hormone-related peptide in calcium homeostasis, bone metabolism, and bone development: the proteins, their genes, and receptors. In: Metabolic Bone Disease, edited by L. V. Avioli, L.V.; Krane, S.M. New York: Academic, 1997; pp. 51-94.

[18] Wu, T. L.; Vasavada, R.C.;Yang, K.; Massfelder, T.; Ganz, M.; Abbas, S.K.; Care, A.D.; Stewart, A.F: Structural and physiological characterization of the mid-region secretory species of parathyroid hormone-related protein. J. Biol. Chem., 1996, 271, 24371-24381.

[19] Goltzman, D.; Peytremann, A; Callahan, E.; Tregear, G.W.; Potts, Jr :Analysis of the requirements for parathyroid hormone action in renal membranes with the use of inhibiting analogues. J. Biol. Chem., 1975, 250, 3199-3203.

[20] Horiuchi, N.; Holick, M.F.; Potts, J.T.jJr., Rosenblatt, M:A parathyroid hormone inhibitor in vivo: design and biologic evaluation of a hormone analog. Science., 1983, 220, 1053- 1055.

[21] Tregear, G. W.; Rietschoten, J.Van.; Greene, E.; Keutmann, H.T.; Niall, H.D.; Reit, B.; Parsons, J.A.; Potts, Jr : Bovine parathyroid hormone: minimum chain length of synthetic peptide required for biological activity. Endocrinology.,1973, 93, 13491353.

[22] Abou-Samra, A.-B.; Uneno, S.; Jüppner, H.; Keutmann, H.; Potts, J.T.; Segre, G.V.;Nussbaum, S.R: Nonhomologous sequences of parathyroid hormone and the parathyroid hormone related peptide bind to a common receptor on ROS 17/2.8 cells. Endocrinology., 1989, 125, 2215-2217. 
[23] Caulfield, M. P.; Rosenblatt. M.:Parathyroid hormone receptor interactions. Trends Endocrinol. Metab., 1990, 2, 164-168.

[24] Barden, J.; Cuthbertson, R.; Jia-Zhen, W.; Moseley, J.; Kemp,B.: Solution structure of parathyroid hormone related protein (residues 1-34) containing an Ala substituted for an Ile in position 15 (PTHrP[Ala15]-(1-34)). J. Biol. Chem., 1997, 273, 2957229578.

[25] Marx, U.; Austermann, S.; Bayer, P.; Adermann, K.; Ejchart, A.; Sticht, H.; Walters, S.; Schmid, F.; Jaenicke, R.;Forssmann, W.; Rosch,P.: Structure of human parathyroid hormone 1-37 in solution. J. Biol. Chem., 1995, 270, 15194-15202.

[26] Pellegrini, M.; Royo, M.;Rosenblatt, M.; Chorev, M.; Mierke,D.: Addressing the tertiary structure of human parathyroid hormone-(1-34). J. Biol. Chem., 1998, 273, 1042010427.

[27] Barden, J. A.; Kemp, B.E.: Stabilized NMR structure of the hypercalcemia of malignancy peptide PTHrP[Ala-26](1- 34)amide. Biochim. Biophys. Acta ., 1994, 1208, 256-262.

[28] Cohen, F. E.; Strewler, G.J.; Bradley, M.S.;Carlquist, M.; Nilsson, M.; Ericsson, M.; Ciardelli, T.L.;and R. A. Nissenson, R. A.: Analogues of parathyroid hormone modified at positions 3 and 6: effects on receptor binding and activation of adenylyl cyclase in kidney and bone. J. Biol. Chem., 1991, 266, 1997-2004.

[29] Gardella, T. J., M. D. Luck, A. K. Wilson, H. T. Keutmann, S. R. Nussbaum, J. T. Potts, Jr., and H. M. Kronenberg. Parathyroid hormone (PTH)/PTH-related peptide hybrid peptides reveal functional interactions between the 1-14 and 15-34 domains of the ligand. J. Biol. Chem.; 1995, 270: 6584-6588.

[30] Mannstadt M, Juppner H, Gardella J T: Receptors for PTH and PTHrP: their biological importance and functional properties. Am. J. Physiol.; 1999, 277, 665-675

[31] Ji, T. H.; Grossmann, M.; Ji,I.: G protein-coupled receptors. I. Diversity of receptorligand interactions. J. Biol. Chem., 1998, 273, 17299-17302.

[32] Segre, G. V.; Goldring,S.R.: Receptors for secretin, calcitonin, parathyroid hormone (PTH)/PTH-related peptide, vasoactive intestinal peptide, glucagon-like peptide 1, growth hormone-releasing hormone, and glucagon belong to a newly discovered $\mathrm{G}$ protein-linked receptor family. Trends Endocrinol. Metab.,1993, 4: 309-314.

[33] Ackerman AM.; Gannon $M$ :Molecular regulation of pancreatic b-cell mass development ,maintenance and expansion . Journal of Molecular Endocrinology., 2007, 38, 193-206.

[34] Bhushan, A.; Itoh, N.; Kato, S.; Thiery, J.P.; Czernichow, P.; Bellusci, S.; Scharfmann, R.: Fgf10 is essential for maintaining the proliferative capacity of epithelial progenitor cells during early pancreatic organogenesis. Development ., 2001, 128 , 5109-5117.

[35] Spooner, B.S.; Walther, B.T.; Rutter,W.J.: The development of the dorsal and ventral mammalian pancreas in vivo and in vitro. Journal of Cell Biology., 1970, 47 , 235246.

[36] Harrison, K.A.; Thaler, J.; Pfaff, S.L.; Gu, H.; Kehrl, J.H.: Pancreas dorsal lobe agenesis and abnormal islets of Langerhans in Hlxb9-deficient mice. Nature Genetics., 1999, 23, 71-75.

[37] Li, H.; Arber, S.; Jessell, T.M.; Edlund, H.: 1999 Selective agenesis of the dorsal pancreas in mice lacking homeobox gene Hlxb9. Nature Genetics., 1999, 23, 67-70. 
[38] Ahlgren, U.; Pfaff, SL.; Jessell, T.M.; Edlund ,T.; Edlund, H.: Independent requirement for ISL1 in formation of pancreatic mesenchyme and islet cells. Nature., 1997, 385, 257-260.

[39] Guz,Y.; Montminy, M.; Stein, R.; Leonard, J.; Gamer, L.; Wright, C.; Teitelman, G.: Expression of murine STF-1, a putative insulin gene transcription factor, in beta cells of pancreas, duodenal epithelium and pancreatic exocrine and endocrine progenitors during ontogeny. Development., 1995, 121, 11-18.

[40] Melloul D.; Marshak S .; Cerasi E : Regulation of $p d x$-1 gene expression. Diabetes., 2002, $51,320-325$.

[41] Offield, M.F.; Jetton, T.L.; Labosky, P.A.; Ray, M.; Stein, R.W.; Magnuson, M.A.; Hogan, B.L.; Wright, C.V: PDX-1 is required for pancreatic outgrowth and differentiation of the rostral duodenum. Development., 1996, 122, 983-995.

[42] Stoffers, D.A.; Zinkin, N.T.; Stanojevic, V.; Clarke, W.L.; Habener,J.F: Pancreatic agenesis attributable to a single nucleotide deletion in the human IPF1 gene coding sequence. Nature Genetics., 1997b, 15, 106-110.

[43] Krapp, A.; Knofler, M.; Ledermann, B.; Burki, K.; Berney, C.; Zoerkler, N.; Hagenbuchle, O.; Wellauer, P.K.: 1998 The bHLH protein PTF1-p48 is essential for the formation of the exocrine and the correct spatial organization of the endocrine pancreas. Genes and Developmen., 1998, 12 , 3752-3763.

[44] Kawaguchi, Y.; Cooper, B.; Gannon, M.; Ray, M.; MacDonald, R.J.; Wright, C.V.: The role of the transcriptional regulator Ptf1a in converting intestinal to pancreatic progenitors. Nature Genetics., 2002, 32, 128-134.

[45] Rhodes, C.J: 2005 Type 2 diabetes - a matter of beta-cell life and death? Science., 2005, 307, 380-384.

[46] [46] Scaglia, L.; Smith, F.; Bonner-Weir, S.: Apoptosis contributes to the involution of beta cell mass in the post partum rat pancreas. Endocrinology., 1995, 136, 54615468.

[47] Vasavada, R.C.; Garcia-Ocaña, A.; Zawalich, W.S.; Sorenson, R.L.; Dann, P.; Syed, M.; Ogren, L.; Talamantes, F.; Stewart, A.F.: Targeted expression of placental lactogen in the beta cells of transgenic mice results in beta cell proliferation, islet mass augmentation, and hypoglycemia. Journal of Biological Chemistry., 2000, 275, 15399-15406.

[48] Cozar-Castellano, I.; Weinstock, M.; Haught, M.; Velazquez-Garcia, S.; Sipula, D.; Stewart, A.F.: Evaluation of beta-cell replication in mice transgenic for hepatocyte growth factor and placental lactogen: comprehensive characterization of the G1/S regulatory proteins reveals unique involvement of p21cip. Diabetes., 2006a, 55, 7077.

[49] Garcia-Ocaña, A.; Takane, K.K.; Syed, M.A.; Philbrick, W.M.; Vasavada, R.C.; Stewart, A.F.: Hepatocyte growth factor overexpression in the islet of transgenic mice increases beta cell proliferation, enhances islet mass, and induces mild hypoglycemia. Journal of Biological Chemistry., 2000, 275 , 1226-1232.

[50] Garcia-Ocaña, A.; Vasavada, R.C.; Cebrian, A.; Reddy, V.; Takane, K.K.; LopezTalavera,J-C.; Stewart, A.F.: Transgenic overexpression of hepatocyte growth factor in the beta-cell markedly improves islet function and islet transplant outcomes in mice. Diabetes., 2001, 50 , 2752-2762. 
[51] Sone, H.; Kagawa, Y.: Pancreatic beta cell senescence contributes to the pathogenesis of type 2 diabetes in high-fat diet-induced diabetic mice. Diabetologia., 2005, 48 , 5867.

[52] Wang, Q.; Brubaker, P.L.: Glucagon-like peptide-1 treatment delays the onset of diabetes in 8 week-old $d b / d b$ mice. Diabetologia., 2002, $45,1263-1273$.

[53] Pick, A.; Clark, J.; Kubstrup, C,.; Levisetti, M.; Pugh, W.; Bonner-Weir, S.; Polonsky, K :1998 Role of apoptosis in failure of beta-cell mass compensation for insulin resistance and beta-cell defects in the male Zucker diabetic fatty rat. Diabetes., 1998, $47,358-364$.

[54] Kubota, N.; Terauchi, Y.; Tobe, K.; Yano, W.; Suzuki, R.; Ueki, K.; Takamoto, I.; Satoh, H.; Maki, T.; Kubota, T: Insulin receptor substrate 2 plays a crucial role in beta cells and the hypothalamus. Journal of Clinical Investigation., 2004, 114 , 917-927.

[55] Hennige, A.M.; Burks, D.J.; Ozcan,U.; Kulkarni, R.N.; Ye, J.;Park, S.; Schubert, M.; Fisher, T.L.; Dow, M.A.; Leshan, R: Upregulation of insulin receptor substrate-2 in pancreatic beta cells prevents diabetes. Journal of Clinical Investigation., 2003, 112 , 1521-1532.

[56] Kitamura, T.; Nakae, J.; Kitamura, Y.; Kido, Y.;Biggs, W.H III.;Wright, C.V.E.; White,M.F.; Arden, K.C.; Accili, D: The forkhead transcription factor Foxo1 links insulin signaling to $\mathrm{Pdx} 1$ regulation of pancreatic beta cell growth. Journal of Clinical Investigation., 2002, 110, 1839-1847.

[57] Okamoto, H.; Hribal, M.L.; Lin, H.V.; Bennett, W.R.; Ward, A.; Accili, D: Role of the forkhead protein FoxO1 in beta cell compensation to insulin resistance. Journal of Clinical Investigation., 2006, $116,775-782$.

[58] García-Ocaña A.; Vasavada CA .; Takane KK.; , Cebrian A .;Lopez-Talavera CJ ..; Stewart AF : Using B-Cell Growth Factors to Enhance Human Pancreatic Islet Transplantation. Journ Endocr. Metab.,2001,86, 984-988.

[59] Broadus, A. E.; Stewart, A. F. in The Parathyroids: Basic and Clinical Concepts (Bilezikian, J. P., Levine, M. A., and Marcus, R., eds), Raven Press, New York, 1994; pp. 259-294.

[60] Orloff, J. J.; Reddy, D.; dePapp, A. E.; Yang, K. H.;Soifer, N. S.; Stewart, A. F. Endocrine Rev., 1994, 15, 40-60 .

[61] Jüppner, H.; Abou-Samra, A.-B.; Freeman, M.; Kong, X. F.; Schipani, E.; Richards, J.; Kolakowski, L. F.; Jr., Hock, J.; Potts, J. T.; Jr., Kronenberg, H.; Segre, G. V. Science., 1991, 254, 1024-1026.

[62] Porter, S.E.; Sorenson, R.L.; Dann, P.; García-Ocaña, A.; Stewart, A.F.; Vasavada,R.C.: 1998 Progressive pancreatic islet hyperplasia in the islet-targeted, PTH-related protein-overexpressing mouse. Endocrinology., 1998, 139, 3743-3751.

[63] Vasavada, R.C.; Cebrian, A.; García-Ocaña, A.: PTH-related protein (PTHrP): in vivo inhibition of streptozotocin-induced $B$ cell death in transgenic mice. Proceedings of the 82nd Annual Meeting of The Endocrine Society , Canada, 2000, p. 76.

[64] Philbrick, W.M.; Wysolmerski, J.J.; Galbraith, S.; Holt, E.; Orloff, J.J.; Yang, K.H.; Vasavada, R.C.;Weir, E.C.; Broadus, A.E.; Stewart, A.F.: 1996 Defining the physiologic roles of parathyroid hormone-related protein in normal physiology. Physiol Rev., 1996, 76, 127-173.

[65] Wysolmerski, J.J.; Stewart, A.F: The physiology of parathyroid hormone-related protein: an emerging role as a developmental factor. Ann Rev Physiol., 1998, 60, 431-460. 
[66] Plawner, L.L.; Philbrick, W.M.; Burtis, W.J.; Broadus, A.E.; Stewart, A.F.: 1995 Secretion of parathyroid hormone-related protein: cell-specific secretion via the regulated $v s$. the constitutive secretory pathway. J Biol Chem., 1995, 270, 14078-14084.

[67] Deftos, L.J.; Burton, D.W.; Brandt, D.W: PTH-like protein is a secretory product of atrial myocytes. J Clin Invest., 1993, 92, 727-735.

[68] Jüppner, H.; Abou-Samra, A-B.; Freeman, M.; Kong, X.F.; Schipani, E.; Richards, J.; Kolakowski, L.F. Jr.; Hock, J.; Potts, J.T. Jr.; Kronenberg, H.M.; Segre, G.V: A G protein-linked receptor for parathyroid hormone and parathyroid hormone-related peptide. Science., 1991, 254, 1024-1026.

[69] Abou-Samra, A-B.; Jüppner, H.; Force, T.; Freeman, M.W.; Kong, X-F.; Schipani, E.; Urena, P.; Richards, J.; Bonventre, J.V.; Potts, J.T .Jr.; Kronenberg, H.M.; Segre, G.V: Expression cloning of a common receptor for parathyroid hormone and parathyroid hormone-related peptide from rat osteoblast-like cells: a single receptor stimulates intracellular accumulation of both cAMP and inositol triphosphates and increases intracellular free calcium. Proc Natl Acad Sci U S A., 1992, 89, 2732-2736.

[70] Stork, P.J.S.; Schmitt, J.M: Crosstalk between cAMP and MAP kinase signaling in the regulation of cell proliferation. Trends Cell Biol ., 2002, 12, 258-266.

[71] Burgering, B.M.T.; Bos, J.L: Regulation of Ras-mediated signalling: more than one way to skin a cat. Trends Biochem Sci., 1995, 20, 18-22.

[72] Vossler, M.R.; Yao, H.; York, R.D.; Pan, M-G.; Rim, C.S.; Stork, P.J.S: cAMP activates MAP kinase and Elk-1 through a B-Raf- and Rap1-dependent pathway. Cell ., 1997, $89,73-82$.

[73] Chen, T.; Cho, R.W.; Stork, P.J.S.; Weber, M.J: Elevation of cyclic adenosine 3',5'monophosphate potentiates activation of mitogen-activated protein kinase by growth factors in LNCaP prostate cancer cells. Cancer Res., 1991, 59, 213-218.

[74] Miller, C.P.; McGehee, R.E.; Habener, J.F: IDX-1: a new homeodomain transcription factor expressed in rat pancreatic islets and duodenum that transactivates the somatostatin gene. EMBO J., 1994, 13, 1145-1156.

[75] Leonard, J.; Peers, B.; Johnson, T.; Ferreri, K.; Lee, S.; Montminy, M.: Characterization of somatostatin transactivating factor-1, a novel homeobox factor that stimulates somatostatin expression in pancreatic islet cells. Mol Endocrinol., 1993, 7, 12751283.

[76] Jonsson, J.; Carlsson, L.; Edlund,T.; Edlund, H: Insulin promoter factor-1 is required for pancreas development in mice. Nature., 1994, 371, 606-609.

[77] Ahlgren, U.; Pfaff, S.; Jessell, T.M.; Edlund, T.; Edlund, H.: 1997 Independent requirement for ISL1 in formation of pancreatic mesenchyme and islet cells. Nature., 1997, 385, 257-260.

[78] Finegood, D.T.; Scaglia, L.; Bonner-Weir, S.: Perspectives in diabetes dynamics of B-cell mass in the growing rat pancreas. Estimation with a simple mathematical model. Diabetes., 1995, 44, 249-256.

[79] Otonkoski, T.; Cirulli, V.; Beattie, G.M.; Mally, M.I.; Soto, G.; Rubin, J.S.; Hayek, A: A role for hepatocyte growth factor/scatter factor in fetal mesenchyme-induced pancreatic ß-cell growth. Endocrinology., 1996, 137, 3131-3139.

[80] Rafaeloff, R.; Pittenger, G.L.; Barlow, S.W.; Qin, X.F.; Yan ,B.; Rosenberg. L.; Duguid, W.P.; Vinik, A.I.: Cloning and expression of the pancreatic islet neogenesis- 
associated protein (INGAP) gene and its expression in islet neogenesis in hamsters. J Clin Invest., 1997, 99, 2100-2109.

[81] Gaich, G.; Orloff, J.J.; Atillasoy, E.J.; Burtis, W.J.; Ganz, M.B.; Stewart, A.F: Aminoterminal parathyroid hormone-related protein: specific binding and cytosolic calcium responses in at insulinoma cells. Endocrinology., 1992, 132, 1402-1409.

[82] Drucker, DJ: Glucagon-like peptides: regulators of cell proliferation, differentiation, and apoptosis. Mol Endocrinol., 2003, 7,161 -171,

[83] Vasavada, R.C.; Cavaliere, C.; D’Ercole, A.J.; Dann, P.; Burtis, W.J.; Madlener, A.L.; Zawalich, K.; Zawalich, W.; Philbrick, W.; Stewart, A.F.: Overexpression of parathyroid hormone-related protein in the pancreatic islets of transgenic mice causes islet hyperplasia, hyperinsulinemia, and hypoglycemia. J Biol Chem ., 1996, $271,1200-1208$.

[84] Baggio, L.; Adatia, F.; Bock, T.; Brubaker, P.L.; Drucker, D.J.: Sustained expression of exendin-4 does not perturb glucose homeostasis, $B$-cell mass, or food intake in metallothionein-preproexendin transgenic mice. J Biol Chem., 2000, 275 , 34471 34477.

[85] Ijunghall, S.; M. Palmer, G.; Akerstrom, Wide, L: Diabetes mellitus, glucose tolerance and insulin response to glucose in patients with primary hyperparathyroidism before and after parathyroidectomy. Eur. J. Clin. Invest., 1983, 13, 373-377.

[86] Kim, H.; R. K. Kalkhoff, N. V. ; Costrini, J. M.; Cerletty.; Jacobson,M.: Plasma insulin disturbances in primary hyperparathyroidism. J. Clin. Invest., 1971, 50, 2596-2605.

[87] Fadda, G. Z.; M. Ak\&ial, L. G.;Lipson.; Massry, S.G.: Direct effect of parathyroid hormone on insulin secretion from pancreatic islets. Am. J. Physiol., 1990, 258 (Endocrinol Metab. 21), E975-E984.

[88] Ishida, H.; Suzuki, K.; Someya, Y.:Possible compensatory role of parathyroid hormone -related peptide on maintenance of calcium homeostasis in patients with noninsulin -dependant diabetes mellitus. Acta Endocrinologica., 1993,129, 519-524.

[89] De Marinis, L.; Merlini, G.; Makhoul, O.; Barbarino, A.: Calcium antagonists and hormone release :IV.Role of calcium in glucose-stimulated early phase insulin in vivo. J Endocrinol Invest., $1982,5,121-4$.

[90] Wu, T.L.; Vasavada, R.C.; Yang, K.; Massfclder, T.; Ganz, M.; Abbas, S.K .: Structural and physiologic characterization of the mid-region secretory species of parathyroid hormone -related protein. J Biol Chem., 1996, 271, 24371-24381.

[91] Drucker, D.J .;Asa, S.L.; Henderson, J.; Glotzman, D.: The PTHrP gene is expressed in the normal and neoplastic human endocrine pancreas . Mol Endocrinol ., 1989, 1589-1595.

[92] Shor, R.; Halabe, A.; Aberbuh, E.;Matas, Z.;Fux, A.;Boaz, M.;Wainstein, J.: PTHrP and insulin levels following oral glucose and calcium administration. European Journal of Internal Medicine., 2006, 17, 408-411.

[93] Legakis, I.;Mantouridis, T.: Positive correlation of PTH-related peptide with glucose in type 2 diabetes. Exp Diabetes Res., 2009,31. 


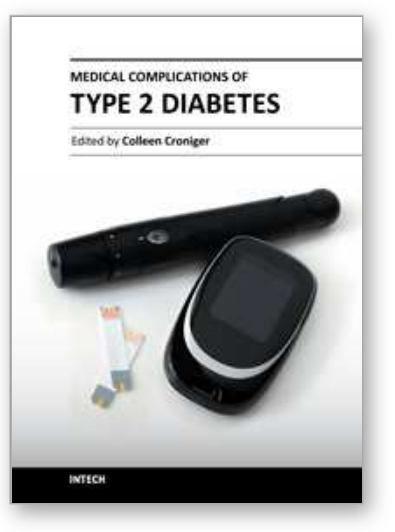

\author{
Medical Complications of Type 2 Diabetes \\ Edited by Dr. Colleen Croniger
}

ISBN 978-953-307-363-7

Hard cover, 412 pages

Publisher InTech

Published online 12, September, 2011

Published in print edition September, 2011

Obesity and type 2 diabetes are increasing worldwide problems. In this book we reviewed insulin secretion in both healthy individuals and in patients with type 2 diabetes. Because of the risk associated with progression from insulin resistance to diabetes and cardiovascular complications increases along a continuum, we included several chapters on the damage of endothelial cells in type 2 diabetes and genetic influences on endothelial cell dysfunction. Cardiovascular complications occur at a much lower glucose levels, thus a review on the oral glucose tolerance test compared to other methods was included. The medical conditions associated with type 2 diabetes such as pancreatic cancer, sarcopenia and sleep disordered breathing with diabetes were also discussed. The book concludes with several chapters on the treatments for this disease offering us hope in prevention and successful alleviation of the co-morbidities associated with obesity and type 2 diabetes.

\title{
How to reference
}

In order to correctly reference this scholarly work, feel free to copy and paste the following:

loannis Legakis (2011). The Role of Parathyroid Hormone-Related Protein (PTHRP) in the Pathophysiology of Diabetes Mellitus, Medical Complications of Type 2 Diabetes, Dr. Colleen Croniger (Ed.), ISBN: 978-953-307363-7, InTech, Available from: http:/www.intechopen.com/books/medical-complications-of-type-2diabetes/the-role-of-parathyroid-hormone-related-protein-pthrp-in-the-pathophysiology-of-diabetes-mellitus

\section{INTECH}

open science | open minds

\author{
InTech Europe \\ University Campus STeP Ri \\ Slavka Krautzeka 83/A \\ 51000 Rijeka, Croatia \\ Phone: +385 (51) 770447 \\ Fax: +385 (51) 686166 \\ www.intechopen.com
}

\author{
InTech China \\ Unit 405, Office Block, Hotel Equatorial Shanghai \\ No.65, Yan An Road (West), Shanghai, 200040, China \\ 中国上海市延安西路65号上海国际贵都大饭店办公楼 405 单元 \\ Phone: +86-21-62489820 \\ Fax: $+86-21-62489821$
}


(C) 2011 The Author(s). Licensee IntechOpen. This chapter is distributed under the terms of the Creative Commons Attribution-NonCommercialShareAlike-3.0 License, which permits use, distribution and reproduction for non-commercial purposes, provided the original is properly cited and derivative works building on this content are distributed under the same license. 